\title{
Pectin-enriched Material from Mandarin Orange Byproducts as a Potential Fat Replacer in Cookies
}

\author{
Agus Prihatin $^{\# 1}$, Chen Shiguo", Ye Xingqian ${ }^{\#}$ \\ \# School of Biosystems Engineering and Food Science, Zhejiang University, Yuhantang Road 866, Hangzhou, 310058, China \\ E-mail: ${ }^{1}$ agusprihatin@zju.edu.cn
}

\begin{abstract}
The production of mandarin orange canned on an industrial level leads to a considerable quantity of residue, which is still considered as waste or used as a complement in agriculture. In general, mandarin orange byproducts have no economic value, even though their composition is rich in soluble sugars, cellulose, hemicellulose, pectin and essential oils that could form the basis of several industrial processes. The purpose of this study was to characterize pectin from byproducts and to study their application as a fat replacer in cookies. When pectin solutions were subjected to steady-shear measurements, shear-thinning behavior was observed. The flow behaviors could be described by the Cross model $(\mathbf{R 2}=\mathbf{0 . 8 4})$, and temperature effects were investigated by the Arrhenius equation. When pectin-enriched material were incorporated into cookie formulations in place of shortening (semisolid fat generally used in baked foods) up to $30 \%$ by the weight of shortening, the cookie spread diameter was reduced while the color has no significant difference with control. Surprisingly, the use of mandarin orange pectin at different prosentation as fat replacer reduce the fat content significantly. Thus mandarin orange pectin proved to be a promising alternative as a fat replacer in cookies production.
\end{abstract}

Keywords - mandarin orange byproducts, pectin-enriched material, fat replacer, cookies.

\section{INTRODUCTION}

The global orange production is about 51 million metric tons [18]. The global amount of transformed orange is 20 million metric tons most of which is transformed in China, Brazil and Europe [18] Although sweet orange (C. sinensis) dominated in the world market, mandarin orange (C. reticulate) is the leading one in China, and it covered over almost two thirds of the whole production of citrus fruits.

Traditionally, the majority of mandarin fruits were consumed freshly, while in recent years, some mandarin fruits were processed to can and exported mainly to USA, Japan, and EU, etc. The storage of mandarin fruits can be prolonged largely after canning. During the production of mandarin orange can, only $50 \%$ of the gross weight of the fruit can be canned; the rest is considered to be the byproduct. The equipment used to process orange can separates by-products into different fractions, typically peel, core and frit. Nevertheless, these wastes may contain valuable substances, such as pigments, sugars, organic acids, flavours and bioactive compounds, such as antioxidants, enzymes, antimicrobial compounds and fibres, therefore they could be applied in bioprocesses generating products with higher added value [13]. Wastes generated from citrus [4], [5], [6] processing industries are reported to be rich source of pectin.
The world market demand for pectin is in excess of 30,000 tons annually and is growing by about $4-5 \%$ per annum [20]. So, citrus-processing industries are commercially interested in recovering residual amounts of pectin.

Pectin is a complex carbohydrate, which is a significant component of the primary cell wall of plants. Pectin is a polymer of $\alpha$-galacturonic acid with a variable number of methyl ester groups. Pectin is a natural food additive used extensively in the food industry as a thickener, a texturiser, an emulsifier, stabilizer, gelling agent and other applications include fat replacers in spreads, salad dressings, ice cream and emulsified meat products [10]. Due to the strong gelling and thickening characteristics, there are considerable difficulties in incorporating high levels of pectin into foods. Therefore, the development of foods with higher levels of pectin acceptable to consumers is being pursued.

There have been previous studies which reported the possible use of the pectin-enriched materials from plant sources. Reference [8] shows produced pectin-enriched products from butternut with the assistance of cell wall hydrolytic enzymes for thickeners in the food industry. Pectin was also used as a fat replacer in low-fat frankfurters [3], [14] and cheeses [11],[12] but fat replacement with pectin has not yet been extended to other types of food. 
TABLE I.

INDUSTRIAL AND BOTANY NAME OF ORANGE BYPRODUCTS

\begin{tabular}{|l|l|l|}
\hline $\begin{array}{c}\text { Industrial } \\
\text { name }\end{array}$ & \multicolumn{1}{|c|}{$\begin{array}{c}\text { Anatomic/ } \\
\text { Botany name }\end{array}$} & \multicolumn{1}{c|}{ Description } \\
\hline Core & Mesocarp & $\begin{array}{l}\text { Also called aledo, corresponding } \\
\text { to 42\% of the total fruit. There is } \\
\text { the white part of fruit }\end{array}$ \\
\hline Peel & Epicarp & Outer coloured part of the fruit \\
\hline Frit & Epicarp & $\begin{array}{l}\text { Outermost part of the epicarp. } \\
\text { The glands that store oil are } \\
\text { concentrated in the outer part of } \\
\text { the pericarp (frit). }\end{array}$ \\
\hline
\end{tabular}

The goals of this study were to isolate pectin- enriched fractions from mandarin orange, investigate their rheological properties, and evaluate their performance as a fat replacer in cookie formulations.

\section{MATERIAL AND METHOD}

\section{A. Material}

Water waste citrus was collected from local mandarin cannery of Huayu Ltd Xiangshan county, Ningbo city, Zhejiang province. Other ingredients as composition of the model cookies such as flour, sugar, brown sugar, shortening, non-fat dry milk, sodium bicarbonate, high-fructose corn syrup, salt and ammonium bicarbonate were all purchased from a local supermarket.

\section{B. Preparation of Pectin From Citrus}

Pectin-enriched material was made from water waste citrus canning process during membrant peeling. Mixed the water waste citrus canning with acid and alkaline by $4: 6, \mathrm{pH}$ is about 5, after that add with 1 volume of ethanol, stir slightly, keep for $2 \mathrm{~h}$, then filtrated by 300 mesh filter cloth, wash the residue 2 times by $90 \%$ ethanol and absolute ethanol respectively, filtrated again as above. Dry the residue at fume hood overnight, then ground them to powder and keep in a plastic bag.

\section{Rheological Measurement}

For rheological measurements, PEM solutions at two different concentrations $(10 \%$ and $20 \% \mathrm{w} / \mathrm{w})$ were loaded onto a stress-controlled rheometer (HAAKE Rheo-stress 6000, Thermo Scientific Instruments, Inc. Germany) with a $40 \mathrm{~mm}$ parallel plate. Steady-shear measurements were made to investigate the flow behaviours of the PEM solutions at a range of shear rates from 1 to $500 \mathrm{~s}-1$ at $250 \mathrm{C}$, which were then characterized by the Cross model as follows:

$$
\eta=\eta \infty+\infty \frac{(n 0-n \infty)}{\left(1+(\lambda \gamma)^{n}\right)}
$$

Where $\eta$ is apparent viscosity, $\eta \infty$ is infinite-shear rate viscosity, $\eta 0$ is zero-shear rate viscosity, $\gamma$ is shear rate, $\lambda$ is structural relaxation time constant, and $n$ is dimensionless power-law index for the Cross equation. In addition, the viscosity of the PEM solutions was analysed as a function of temperature by increasing the temperature from 20 to $800 \mathrm{C}$ at a constant shear rate of $100 \mathrm{~s}-1$. Arrhenius equation was then applied to investigate the viscosity dependence on temperature [16].

$$
\eta=\mathrm{A} . \operatorname{EXP}\left(\frac{\mathrm{Ea}}{\mathrm{RT}}\right)
$$

Where $\eta$ is the viscosity of the PEM solutions, A is the pre-exponential factor, Ea is the activation energy, $\mathrm{R}$ is the gas constant, and $\mathrm{T}$ is the absolute temperature. The activation energy was obtained from the slope of a $\operatorname{In}(\eta)$ versus $1 / \mathrm{T}$ plot.

\section{Cookies Preparation}

Reference [1] shows the formulation for the control cookie contained the following ingredients; $225 \mathrm{~g}$ pastry flour, $72 \mathrm{~g}$ sugar, $22.5 \mathrm{~g}$ brown sugar, $100 \mathrm{~g}$ shortening, $2.3 \mathrm{~g}$ non-fat dry milk, $2.3 \mathrm{~g}$ sodium bicarbonate, $3.4 \mathrm{~g}$ highfructose corn syrup, $2.8 \mathrm{~g}$ salt, $1.1 \mathrm{~g}$ ammonium bicarbonate, and $49.5 \mathrm{~g}$ water. For shortening replacement, pectin gels were prepared by dispersing pectin powders in distilled water at a concentration of $30 \%$ with agitation. The pectin gels were incorporated into the cookie formulations by replacing shortening $(10 \%, 20 \%, 30 \%, 40 \%$ and $50 \%)$ on an equal weight basis.

Shortening was mixed with sugar, brown sugar, nonfat dry milk, salt, and sodium bicarbonate on speed 1 for $3 \mathrm{~min}$ by using a KitchenAid mixer (Joyoung, China) equipped with a paddle beater. Then, the mixture of high-fructose corn syrup and water with ammonium bicarbonate was added and mixed for 1 min on speed 1, followed by scraping down and mixing for an additional minute on speed 2. After flour was added, the mixing was continued for 2 min with scraping down every $30 \mathrm{~s}$. The cookie dough was flattened with a rolling pin, cut into cylindrical shapes $(47 \mathrm{~mm}$ diameter and $17 \mathrm{~mm}$ thickness) with a cookie cutter, baked at $1800 \mathrm{C}$ for $14 \mathrm{~min}$, cooled at a room temperature, and sealed in a plastic bag until measurements were taken.

\section{E. Measurement of Cookies Geometry}

Reference [1] shows the average diameter of a cookie was measured from the total diameter of six cookies which were placed next to each other and then rotated by 90 four times. Six cookies were then stacked twice in different order and the total height was used to calculate the average height of a cookie.

\section{F. Color Measurement}

Trimulus colorimeter (Kangguan SC-80C) was used to investigate color changes of cookies in which shortening was replaced with pectin. The values of $\mathrm{L}^{*}$ (lightness/darkness), $\mathrm{a}^{*}$ (redness/greenness), and $\mathrm{b}^{*}$ (yellowness/blueness) were recorded.

\section{G. Composition Analysis}

The amounts of moisture and ash in the cookies samples were measured by [2] official method. Total protein and total fat content of the cookies were determined using the Kjeldahl, and the Soxhlet method, respectively. The protein content of cookies was calculated by multiplying the total nitrogen content by 6.25. Carbohydrates were determined by 
subtracting the sum of moisture, protein, fat, and ash percentages from $100 \%$.

\section{H. Statistical Analysis}

All experiments were carried out in triplicate. Results were statistically analysed by analysis of variance (ANOVA), followed by Duncan's multiple range test. Statistical significance was indicated at a confidence level of $95 \%$.

\section{RESULT AND DISCUSSION}

\section{A. Rheological Characterization of Pectin-enriched Materials from Mandarin Citrus}

As presented in Table II, decreases in the values of $\lambda$ and $\eta 0$ with increasing pectin concentrations were observed, indicating the shift of the Newtonian-limit to lower shear rates and the increase in the zero-shear rate viscosity, respectively. Furthermore, the Cross model was found to be appropriated to characterize the flow behaviours of the pectin solutions. All the pectin solutions possessed values of $\mathrm{n}$ which were less than unity, confirming their shear-thinning characteristics. When the flow curves were described by the Arrhenius equation, the activation energy which is an indicator of the sensitivity of a material to temperature changes, ranged from 1.556 to $5.836 \mathrm{~kJ}$ mol -1 . No correlation between activation energy and pectin concentrations was detected.

TABLE II

Cross Model Parameters Of Pectin Solutions At DifFEREnT CONCENTRATION (10\% AND 20\%)

\begin{tabular}{|l|l|l|}
\hline & \multicolumn{1}{|c|}{$10 \%$ pectin } & \multicolumn{1}{c|}{$20 \%$ pectin } \\
\hline$\eta 0$ (Pa.s) & $3.467 \mathrm{e}+06$ & $2.019 \mathrm{e}+06$ \\
\hline$\lambda(\mathrm{s})$ & $3.544 \mathrm{e}-24$ & $3.181 \mathrm{e}-25$ \\
\hline $\mathrm{n}$ & $2.419 \mathrm{e}-05$ & $3.971 \mathrm{e}-05$ \\
\hline $\mathrm{R} 2$ & 0.84 & 0.48 \\
\hline
\end{tabular}

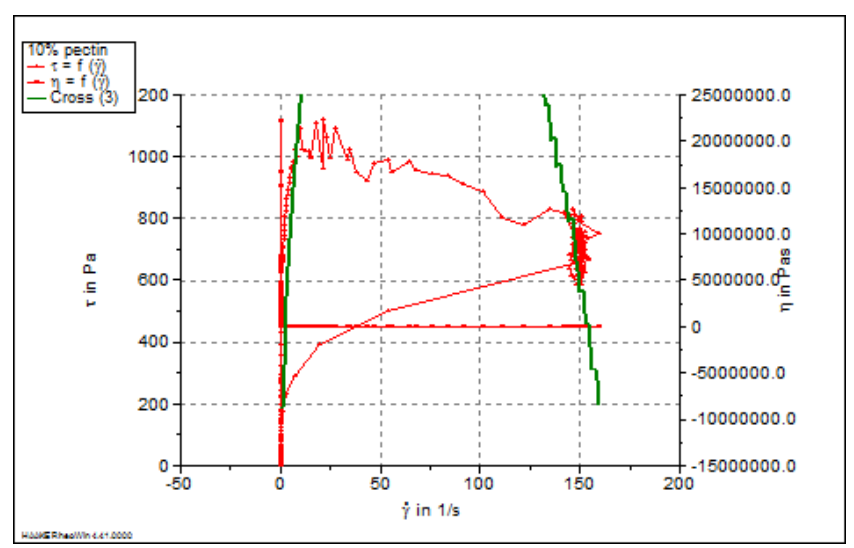

Fig 1 . The flow behavior $10 \%$ pectin solution.

\section{B. Measurement of Cookies Geometry}

The spread factor is another important characteristic in determining the quality of cookies [15]. Pectin incorporation significantly affected the spread factor of the cookies show at Table III.

TABLE III

PHySICAL PROPERTIES OF COOKIES SAMPLE

\begin{tabular}{|c|c|c|c|}
\hline Cookies & Width (mm) & Thickness $(\mathrm{mm})$ & Spread factor \\
\hline Control & $52.68 \pm 0.22 \mathrm{~d}$ & $19.35 \pm 0.54 \mathrm{~b}$ & $2.72 \pm 0.07 \mathrm{a}$ \\
\hline $10 \%$ Pectin & $51.78 \pm 0.03 \mathrm{c}$ & $19.38 \pm 0.08 \mathrm{a}$ & $2.67 \pm 0.01 \mathrm{a}$ \\
\hline $20 \%$ Pectin & $51.63 \pm 0.13 \mathrm{c}$ & $19.33 \pm 0.33 \mathrm{a}$ & $2.67 \pm 0.06 \mathrm{a}$ \\
\hline $30 \%$ Pectin & $49.05 \pm 0.04 \mathrm{~b}$ & $19.54 \pm 0.12 \mathrm{a}$ & $2.51 \pm 0.02 \mathrm{~b}$ \\
\hline $40 \%$ Pectin & $48.42 \pm 0.40 \mathrm{a}$ & $19.34 \pm 0.22 \mathrm{a}$ & $2.50 \pm 0.05 \mathrm{~b}$ \\
\hline $50 \%$ Pectin & $48.40 \pm 0.36 \mathrm{a}$ & $18.26 \pm 0.11 \mathrm{a}$ & $2.65 \pm 0.04 \mathrm{a}$ \\
\hline
\end{tabular}

a-d means within column followed by different superscripts letters are significantly different at $\mathrm{P}<0.05$

As the substitution level of pectin increased, the cookie width and thickness marginally decreased, and thus the spread factor decreased. During baking, cookies expand in all directions and then collapse under their own weight, allowing the cookies to spread [9]. Hence, cookie spread is one of the important physical attributes of cookies. Cookies having higher spread ratio are considered higher spread as the desirable quality attributes [19]. When incorporated into cookie formulations as a fat replacer, pectin is affected the dimensions of cookies after baking. While the control had the greatest diameter $52.68 \pm 0.22$, but the least height is $50 \%$ pectin 48.40 \pm 0.36 . Cookies in which shortening was replaced with pectin globally exhibited reduced diameter and height. It is noteworthy that the replacement of shortening start from $30 \%$ significantly reduce the cookies spread, it appears that pectin were not able to provide the same level of gas retention as shortening. Viscosity of the cookie dough in the oven is known to affect the spread of cookies [17].

\section{Composition Analysis}

The composition analysis and caloric values of the cookies containing fat mimetics are listed in Table IV. As can be seen, with the increase of fat replacers, moisture content significantly increases, however the fat content significantly decreased. The moisture content increased with addition of fat replacer due to very high moisture content of fat replacer preparation, which were typical characteristic of carbohydrate or protein-based fat replacers. The slight decrease of protein and increase of ash was derived from the raw material pectin, which contains a small amount of protein and ash.

In terms of energy value, for substituting $10 \%$ of fat, the energy value decrease by about $2.97 \%$, and the effect is significant. Besides water as a main component of fat mimetic sample, the pectin itself is non-caloric because it is not digested or absorbed in the human digestive tract. 


\section{Colour Measurement}

The colour, with texture and taste, is an important characteristic in determining the acceptability of cookies [21]. As it is shown in Table $\mathrm{V}$, the cookies containing pectin as fat replacer displayed slightly higher lightness $\left(\mathrm{L}^{*}\right)$, redness $\left(a^{*}\right)$ and yellowness $\left(b^{*}\right)$ values than the control cookie. The brightness $\left(\mathrm{L}^{*}\right)$ of cookie added with analogues is significantly higher than that of full fat sample. The $b^{*}$ stands for yellow-blue value, therefore $+b^{*}$ stands for the increase of yellow, and $-b^{*}$ stands for the increase of blue.

TABLE IV

Chemical Composition AND CAloric Values Of CoOKIES

\begin{tabular}{|l|c|c|c|c|c|c|}
\hline & Control & $10 \%$ pectin & $20 \%$ pectin & $30 \%$ pectin & $40 \%$ pectin & $50 \%$ pectin \\
\hline Moisture content & $8.70 \pm 0.03 \mathrm{e}$ & $10.64 \pm 0.09 \mathrm{~d}$ & $11.73 \pm 0.08 \mathrm{c}$ & $12.61 \pm 1.28 \mathrm{bc}$ & $13.32 \pm 0.65 \mathrm{~b}$ & $15.46 \pm 0.25 \mathrm{a}$ \\
\hline Fat & $10.65 \pm 0.23 \mathrm{e}$ & $9.91 \pm 0.18 \mathrm{~d}$ & $9.10 \pm 0.05 \mathrm{c}$ & $8.47 \pm 0.44 \mathrm{~b}$ & $8.31 \pm 0.03 \mathrm{~b}$ & $7.53 \pm 0.19 \mathrm{a}$ \\
\hline Carbohydrate & $74.67 \pm 0.32 \mathrm{a}$ & $73.4 \pm 0.18 \mathrm{~b}$ & $72.09 \pm 0.10 \mathrm{~b}$ & $72.77 \pm 0.52 \mathrm{bc}$ & $72.33 \pm 0.66 \mathrm{c}$ & $70.95 \pm 0.23 \mathrm{~d}$ \\
\hline Protein & $5.62 \pm 0.17 \mathrm{~b}$ & $5.55 \pm 0.14 \mathrm{ab}$ & $5.49 \pm 0.05 \mathrm{ab}$ & $5.51 \mathrm{~V} 0.20 \mathrm{ab}$ & $5.42 \pm 0.04 \mathrm{ab}$ & $5.32 \pm 0.07 \mathrm{a}$ \\
\hline Ash & $0.36 \pm 0.15 \mathrm{~b}$ & $0.50 \pm 0.19 \mathrm{ab}$ & $0.59 \pm 0.02 \mathrm{a}$ & $0.64 \pm 0.17 \mathrm{a}$ & $0.62 \pm 0.07 \mathrm{a}$ & $0.74 \pm 0.04 \mathrm{a}$ \\
\hline Caloric values & $417.04 \pm 1.64 \mathrm{e}$ & $404.99 \pm 0.97 \mathrm{~d}$ & $396.20 \pm 0.29 \mathrm{c}$ & $389.37 \pm 6.67 \mathrm{~b}$ & $385.82 \pm 2.95 \mathrm{~b}$ & $372.82 \pm 1.25 \mathrm{a}$ \\
\hline
\end{tabular}

a-e means within column followed by different superscripts letters are significantly different at $\mathrm{P}<0.05$

TABLE V

COLOR PROPERTIES OF COOKIES SAMPLE

\begin{tabular}{|c|c|c|c|}
\hline & $\mathrm{L} *$ (lightness) & $\mathrm{a} *$ (redness) & $\mathrm{b} *$ (yellowness) \\
\hline Control & $60.58 \pm 2.16 \mathrm{c}$ & $5.18 \pm 1.55 \mathrm{~b}$ & $27.17 \pm 1.66 \mathrm{c}$ \\
\hline $10 \%$ pectin & $63.38 \pm 2.17 \mathrm{bc}$ & $7.06 \pm 3.40 \mathrm{~b}$ & $26.61 \pm 2.12 \mathrm{c}$ \\
\hline $20 \%$ pectin & $65.01 \pm 3.35 \mathrm{~b}$ & $6.21 \pm 2.48 \mathrm{~b}$ & $33.14 \pm 0.35 \mathrm{~b}$ \\
\hline $30 \%$ pectin & $65.08 \pm 1.90 \mathrm{~b}$ & $8.25 \pm 1.31 \mathrm{~b}$ & $37.00 \pm 0.18 \mathrm{a}$ \\
\hline $40 \%$ pectin & $75.77 \pm 1.97 \mathrm{a}$ & $15.55 \pm 2.36 \mathrm{a}$ & $36.91 \pm 0.20 \mathrm{a}$ \\
\hline $50 \%$ pectin & $73.61 \pm 1.30 \mathrm{a}$ & $14.38 \pm 1.45 \mathrm{a}$ & $37.93 \pm 0.37 \mathrm{a}$ \\
\hline
\end{tabular}

a-c means within column followed by different superscripts letters are significantly different at $\mathrm{P}<0.05$

Sample added with analogues is different with whole cookie in the yellow colour. This difference is caused by the reduction of the shortening which contribution a lot to the colour of cookie. Analysis of variance shows that $10 \%$ pectin has no significant difference with control, but by replacing $20 \%$ pectin on the shortening the cookies have lighter surface colour compared with the control. Overall starting from $40 \%$ pectin replacing the fat it was significantly changes the lightness, greenness and yellowness. The colour of a cookie is generated mainly during baking process from the Maillard reaction between reducing sugars and protein. Starch dextrinization and caramelization which are induced by heating also affected the cookie colour [7]. However, [7] suggested that protein content was negatively correlated with lightness of a cookie, indicating that the Maillard reaction played the major role in colour formation. Therefore, the increase in lightness by incorporating pectin in the cookie could be attributed to the decrease in the total protein content.

\section{CONCLUSIONS}

Pectin-enriched materials from mandarin orange were evaluated as a fat replacer in cookies from a geometry, colour, and composition analysis point of view. The results suggest that pectin could be a fat replacer in baked goods, thus allowing production of potentially healthier food items. It could be quite worthwhile for commercial applications since health and wellness is a dominant trend of the current food industry.

\section{REFERENCES}

[1] AACC. Approved Methods of the AACC (American Association of Cereal Chemists). The Association, St Paul, MN.1995.

[2] AOAC .The official methods of analysis, 17th edition. Association of Official Analytical Chemists, Washington.2000.

[3] Candogan, K., Kolsarici, N. "Storage stability of low-fat beef frankfurters formulated with carrageenan or carrageenan with pectin". Meat Sci. 64, 207-214.2003.

[4] Cerezal, P., Larrauri,J. A., \& Pinera, R. M. Factors influencing the use of fruits and vegetables by products in Cuba. Alimentaria, 268, 101-105.1995.

[5] Cho, C. W., Lee, D. Y., \& Kim, C. W. "Concentration and purification of soluble pectin from mandarin peels using cross flow micro-filtration system". Carbohydrate Polymers, 54(1), 21-26.2003.

[6] Contreras-Esquivel,J. C., Hours, R. A., Voget, C. E., \& Mignone, C. F. "Aspergillus kawachii - Produces an acidic pectin releasing enzyme activity".Journal of Bioscience and Bioengineering, 88(1), 48-52.1999.

[7] Chevallier, S., Colonna, P., \& Lourdin, D. "Contribution of major ingredients during baking of biscuit dough systems". Journal of Cereal Science, The 31, 241-252. 2000.

[8] Fissore, E.N., Ponce, N.M., Wider, E.A., Stortz, C.A., Gerschenson, L.N., Rojas, A.M. "Commercial cell wall hydrolytic enzymes for 
producing pectin-enriched products from butternut (Cucurbita moschata, Duchesne ex Poiret)". J. Food Eng. 93, 293-301.2009.

[9] Lee, S., Inglett, G.E." Rheological and physical evaluation of jetcooked oat bran in low calorie cookies”. Int. J. Food Sci. Technology. 41, 553-559.2006.

[10] Liu, Y., Shi, J., \& Langrish, T. A. G. "Water-based extraction of pectin from flavedo and albedo of orange peels". Chemical Engineering Journal , 123(3), 203-209.2006.

[11] Lobato-Calleros, C., Robles-Martinez, J.C., Caballero-Perez, J.F., Vernon-Carter, E.J., Aguirre-Mandujano, E. "Fat replacers in low-fat Mexican manchego cheese”. J. Texture Stud. 32, 1-14.2001.

[12] Lobato-Calleros, C., Vernon-Carter, E.J., Sanchez-Garcia, J., GarciaGalindo, H.S. "Textural characteristics of cheese analogs incorporating fat replacers". J. Texture Stud. 30, 533-548. 1999.

[13] Martínez, R., Torres, P., Meneses, M. A., Figueroa, J. G., PérezÁlvarez, J. A., \& Viuda- Martos, M. "Chemical, technological and in vitro antioxidant properties of mango, guaya, pineapple and passion fruit dietary fibre concentrate". Food Chemistry, 135, 1520-1526.2012.

[14] Pappa, I.C., Bloukas, J.G., Arvanitoyannis, I.S. "Optimization of salt, olive oil and pectin level for low-fat frankfurters produced by replacing pork backfat with olive oil". Meat Sci. 56, 81-88.2000.
[15] Pareyt, B., Talhaoui, F., Kerckhofs, G., Brijs, K., Goesaert, H., Wovers, M., et al. "The role of sugar and fat in sugar-snap cookies: structural and textural properties”. Journal of Food Engineering, 90, 400-408.2009.

[16] Steffe, J.F. Rheological Methods in Food Process Engineering. Freeman Press, east Lansing, MI.1996.

[17] Tsen CC, Bauck LJ, Hoover WJ. "Using surfactants to improve the quality of cookies made from hard wheat flours". Cereal Chem 52: 629-637.1975.

[18] United States Department of Agriculture Foreign Agricultural Service (2014) Citrus: World markets and trade.[Online]. Available:http://www macrophages of.fas.usda.gov/data/citrusworld-markets-and-trade .

[19] Yamamoto H, Worthington ST, Hou G, Ng PKW. "Rheological properties and baking qualities of selected soft wheats in the United States”. Cereal Chem 73:215-221.1996.

[20] Yeoh, S., Shi, J., \& Langrish, T. A. G. "Comparisons between different techniques for water-based extraction of pectin from orange peels”. Desalination, 218, 229-237.2008.

[21] Zucco, F., Borsuk, Y., \& Arntfield, S. D. "Physical and nutritional evaluation of wheat cookies supplemented with pulse flours of different particle sizes”. LWT- Food Science and Technology, 44, 2070-2076.2011. 